IBIMA Publishing

Journal of Marketing Research \& Case Studies

http://www.ibimapublishing.com/journals/JMRCS/jmrcs.html

Vol. 2016 (2016), Article ID 265916, 20 pages

DOI: $10.5171 / 2016.265916$

Research Article

\title{
The Effects of Brand Relationship Quality on the Participation of the Consumer in Boycott
}

\author{
Haykel BEN KHELIL and Néji BOUSLAMA \\ Faculty of Economic Sciences and Management of Tunis
}

Correspondence should be addressed to: Haykel Ben Khelil; benkhelil.haykel@gmail.com

Received date: 4 February 2015; Accepted date: 15 May 2015; Published date: 14 January 2016

Academic Editor: Omneya Mokhtar Yacout

Copyright (C) 2016. Haykel BEN KHELIL and Néji BOUSLAMA. Distributed under Creative Commons CC-BY 4.0

\begin{abstract}
Commitment is a pillar of the consumer-brand relationship. It is often presented as the will of a customer to continue the relationship with its brand. Although this relational current is very studied by researchers, there still remains little developed. Thus, the literature did not examine the combination of commitment-boycott. This thesis aims on the one hand to develop the theoretical framework for the quality of the relationship with the brand and to improve understanding of the role of the perceived egregiousness between the quality of the relationship and the boycott decision. The final survey shows that an effect of assimilation occurs and the consumer will have the intention to continue the relation when the gravity committed by the brand is of an economic nature. However, a contrast effect is released when the perceived gravity is qualified ethical where the commitment of the consumer will maximize this serious act and consequently, they will be ready to participate in a boycott action.
\end{abstract}

Keys words: commitment, quality of the relation, perceived egregiousness, boycott

\section{Introduction}

The notion of relationship dominates the contemporary marketing theory and practice. It makes part of the relational approach which is widely developed in industrial marketing, where social relations are of an important value (Parvatiyar and Sheth, 2000). Therefore, the brand is the major element of this relationship and one of the main ways that can explain the complexity of the consumer's behavior (Belk, 1992). Gradually, the brand becomes an intermediary to build lasting relationships with consumers where they develop a specific commitment to a particular brand category (Schouten, Alexander Mc 1985). Many marketing research studies have shown the key role of commitment in the development of relations between partners (Moorman, Zaltman and Desphande, 1992; Frisou, 2008). Commitment is often perceived as the will of a customer to continue the relationship with their mark; they justify purchasing again the brand and establish a fidelity extension. Indeed, it is important to know that when the consumer develops a relationship of quality with the brand, they will have the intention or not to continue the relationship. This notion has been the subject of several research works where a

Cite this Article as: Haykel BEN KHELIL and Néji BOUSLAMA (2016), "The Effects of Brand Relationship Quality on the Participation of the Consumer in Boycott", Journal of Marketing Research \& Case Studies, Vol. 2016 (2016), Article ID 265916, DOI: 10.5171/2016.265916 
significant number of authors consider that relational marketing must necessarily analyze the consumer's behavior in a postpurchase perspective and check the continuity of the relationship (Morgan et Hunt, 1994, Berry 1995), especially when we sometimes find ourselves face to face with practices that are judged to be unethical. This leads consumers to react increasingly in resistance actions and anticonsumption and refuse to buy certain products or brands (Kozinets and Handelman, 1998). The boycott is then one of these forms of resistance that has been developed in recent years to protect the interests of society in general and consumers in particular. Accordingly, a number of researchers have examined the relationship between the components of the quality of the relationship with the brand (satisfaction, trust and commitment) and the participation in a boycott action. Today, in order to maintain their market share and to counter the boycott phenomenon, the managers' main answer is the improvement and strengthening of the bond between them and their consumers. This necessarily includes meeting the expected needs and satisfactions, the creation of trust and the development of a strong commitment in the relationship with the brand. These variables that characterize the components of the quality of the relationship would probably reduce the participation of current consumers in the boycott (Garbarino and Johnson, 1999). Indeed, studies established in the field of goods of a high consumption show that satisfaction, trust and commitment in the relationship do not have a direct effect on the boycott decision (John and Klein, 2003). The impact is of a second order which is manifested through the perceived severity. Relational quality and commitment in the relationship lead consumers to restrict the perceived severity of the acts committed by the brand, which indirectly helps to reduce their participation in the boycott. Indeed, the perceived severity refers to intolerable, unfair and shocking acts committed by the brand as the nuisance of the environment, exploitation of children, abusive price policy ... to the extent that consumers consider that they deserve to be sanctioned. However, and from another point of view, some authors consider that satisfaction, trust and commitment accentuate the perceived severity of the acts of the brand and thus indirectly lead consumers to participate in the boycott.

Given these two considerations, and from a theoretical point of view, marketing research shows that commitment, quality of relationship and perceived severity explain this boycott behavior where these later have an essential role in consumer decision in continuing or putting an end to the relationship with the brand. These theoretical findings lead us to propose the following research question:

To what extent the development of commitment and brand relationship quality affect consumer participation in a boycott?

\section{Theoretical background}

\section{Brand Relationship Quality}

Relational quality is a fundamental concept in the literature of marketing. The theoretical base of this construct knew an absence of a precise definition and a lack of unanimity on its dimensions (Huntley, 2006; Qin, Zhao and Yi, 2009). Indeed, Woo and Ennew (2004) showed that the definition of the quality of the relationship is bound to the dimensions which compose it. Also, Hennig-Thurau (2002) and Mimouni and Volle (2003) showed that the relational quality reflects "the ability of a relationship to meet the customer requirements." In addition, relational quality is a relevant indicator which shows the intensity of the relationship in time (Smith, 2005; Roux, 2014). In general, most researchers such as Hennig-Thurau and Klee (2002) have defined the quality of the relation as "a global judgment about the ability of the relation to satisfy customer requirements." Within this framework, Henning Thurau Gremler and Gwinner (2002) propose a three-dimensional conceptualization: perceived quality, satisfaction and commitment. Moreover, relationship marketing showed that the relational quality is composed of several interrelated dimensions which vary in number and type according to the context of study. 


\section{The components of the brand relationship quality \\ - Customer satisfaction}

Satisfaction develops cooperation between the various parts of the exchange (Ganesan, 1994). It is regarded as one of the components of the quality of the relationship which can prevent participation in an act of boycott. In a transactional context, consumer satisfaction results from a specific experience of purchase and consumption of a particular brand, product or service (Oliver, 1997). However, the decision of the participation in the boycott is interested rather in the relational context of satisfaction with the brand, which represents the accumulated experiences with it (Garbarino and Johnson, 1999; N'Goala, 2003; Mc Alexander et al. 2003). The satisfied customers are necessarily committed to the brand (Jolley, Mizerski, and Doina, 2006). Dissatisfied customers can remain faithful to their suppliers, for lack of alternatives or because the switching costs are too high.

\section{- Customer trust}

Trust allows the customer to maintain and develop the relationship on the long term (Sirieix and Dubois, 1999). It does not support the participation in the boycott because it constitutes an element of attachment on the long term (Morgan and Hunt, 1994; N'Goala, 2003; Garbarino and Johnson, 1999). According to Sirieix and Dubois (1999), the trust of the consumer in the brand is based on "the credibility of the company and the interest which it carries to the satisfaction of its customers." Also, Gurviez (1998) defines trust in the brand as "the whole, of the promises made by the brand to its customers ". Several researchers in social psychology and relational marketing affirm that trust is an essential factor in the building of the longterm relations (Morgan and Hunt, 1994; Garbarino and Johnson, 1999). So, we conclude that trust contributes to the commitment which exists in a positive and significant relation between these two concepts (Aurier and al 2001).

\section{- Customer commitment}

According to Heilbrunn (1996), commitment expresses the will and intention of the consumer to maintain the same relationship even if they will make sacrifices. It makes it possible to prevent the participation in a boycott and does not allow the dissolution of the relationship. Thus, the degree of commitment plays the main role in the development of the longterm relationships in particular in unfavorable events or incoherent situations. The commitment to the brand is related to this expressive function, where the brand symbolizes the values, beliefs, which we want to share (Onkvisit and Shaw, 1987).

\section{Understanding the Participation of the Consumer in Boycott}

The boycott appears as the negative dimension of responsible consumption. The responsible consumer will resort to the boycott in order to punish the brand. Indeed, Friedman (1985) defines the consumer boycott as "an attempt by one or more parts to reach certain goals by pushing individual consumers to refrain from doing some shopping at the market." This definition is based on both individual consumers and objectives of boycotts. Boycott actions are therefore considered as means to achieve ends. Garrett, (1987) gives a different view, by considering that the boycott is "a concerted refusal to do business with a particular person or company to obtain concessions or to express dissatisfaction with certain acts or practices of the person or the company". According to this definition, the boycott appears as a reaction towards a serious committed act. This definition is limited to organized collective actions and does not take into account individual actions of resistance that are also important (Penaloza and Price 1993; Gabriel and Lang 1995).

In 1985, Friedman has identified two main reasons that are applied at an organizational level: instrumental and expressive. This author has shown that boycotts, whatever their expressive or instrumental nature, should not have the same effects. 


\section{- The instrumental boycott}

This is a reaction to an act committed by the company, whose purpose is creating change, forcing the target to change a practice or a specific policy. Its goals are specific, measurable, such as bringing down the prices of a particular product.

\section{- The expressive boycott}

It directly influences the consumers' perception that they have of themselves, their skills and their characteristics in relation to their environment (Filser, 1994) and their perception of the brand they usually consume. This type of boycott is based on the frustrations and discontent of boycotters and their willingness to express feelings of anger or avoid the feeling of guilt. According to Klein et al. (2003), the boycott decision is triggered by a number of patterns that can be both expressive and instrumental.

\section{The perceived severity of acts committed by the brand}

Perceived severity is a concept borrowed from Klein and al works $(2002,2004)$ and Smith (2005) who use the term "Perceived egregiousness". This term means that the act is seen as outrageously bad, awful, reprehensible and unforgivable. These authors use the term to refer to the high intensity of severity of the brand behavior that is perceived as unacceptable, which exceeds the threshold of the consumer's acceptability and tolerance and that diverges with the principles set by the company. In their article, Chen and al (2014) use the term "perceived moral violation" to express the assessment of the consumer and his way of perceiving the action of violation. In other research work, we find the term "perceived mistake" which consists of the perception and evaluation of the consumer of the action taken by the company. A Careful study of the perceived severity revealed the existence of a sense of betrayal from the brand to the consumer, resulted from a perception of behavioral severity acts and gives the desire to consumers to make that mark pay its overruns and creates in them an intention to boycott it (Sen et al, 2001 and Klein et al, 2004). In this case, the boycott is driven by the consumer's own assessment that is based on their perception of the moral violation of the company, its promises and its commitments towards its consumers. John Klein and Smith, (2003) argue that the perceived severity of the act influences positively on the boycott behavior in a way that the severity arouses the desire within consumers to boycott a brand.

The effect of the relationship quality on the perception of the brand act

The cumulative satisfaction, trust and commitment characterize the quality of the relationship that the consumer establishes towards a particular brand (Garbarino and Johnson, 1999; DeWulf, OdekerkenSchroder and Iacobucci, 2001), however the boycott action of a trademark is to call into question this set of beliefs and generate strong cognitive dissonance (Festinger, 1957). Through this observation, the individual is led to two contradictory effects that constitute perceptual biases depending on the perceived difference between the stimulus (boycott) and the anchoring point of the individual (beliefs about the brand) (Poncin and Pieters, 2002). This opposition is manifested when the assimilation effect is related to the presence of the stimulus in the acceptance range. The consumer is then invited to mitigate the perceived difference between the stimulus and the anchor point (Fishbein and Ajzen, 1981). In the opposite side, the contrast effect is characterized by the presence of the stimulus in the margin of rejection. To better understand the effect of the quality of the relationship on the brand on the boost or cut of the perceived seriousness, we will examine the assimilation-contrast theory.

\section{The assimilation-contrast theory}

Several researchers (John and Klein, 2003; Sherif and Hovland, 1965) assert that "an individual who is faced with a series of stimulus tends to form a psychological scale to evaluate them. The judgments of the stimulus are then made on the base of the categories on the reference scale, an anchor points ". Assimilation and contrast are associated with an opposite perception of two different phenomena according to a 
reference scale and in the context in which they are judged (Poncin and Pieters, 2000). In fact, according to this theory the individual cannot judge the stimulus in an absolute way, they often made it from a reference in their memory or that belongs to their environment. But assimilation is used to mitigate the perceived difference between the two stimuli. On the other side, contrast is used to increase the perceived difference between the two stimuli. We notice that the assimilation and contrast effects are completely opposite but not incompatible; it is the difference between the two processes that provides a net result of either assimilation or contrast (Abeele and Gendolla, 1999).

We note the absence of studies on the role of perceived seriousness in the limitation or accentuation of the boycott decision and without taking into account the importance of the role of different forms of severity in explaining this phenomenon. Therefore, the use of a qualitative exploratory study is very important.

\section{Pre-investigation: An exploratory qualitative research}

The literature offers us a first basis for reflection on the effect of commitment on the contribution in the limitation or accentuation of the boycott action. The literature review revealed a lack of studies of the role of different forms of severity (ethic and economic) in explaining the boycott decision. However, we see that it is necessary to confront these theoretical findings in a support of an exploratory study. For this purpose, the qualitative method aims firstly to expand the field of reflection on the basic concepts of this work while examining the crucial role of severity between the relationship with the brand and the boycott decision. On the other hand, interviews will allow us to have a corpus for the development of items allowing the evaluation of the scale of measuring of the perceived severity. For this issue, we have chosen the type of semistructured interviews. Thus, semistructured interviews are intended to clarify and look further into concepts (Ghiglione and Matalon, 1978). The analysis of contents was carried out using the software Nvivo 8. Based on the literature review, interrogatory questions were proposed and formulated that have allowed us to develop two interview guides each of which included a case of a mark that has committed serious acts and sustained boycott actions. The first interview guide with 11 Tunisian consumers ( 7 females and 4 males) includes the case of Benetton mark. The choice of this brand is justified by its strong reputation in the Tunisian consumer, knowing that two-thirds of the products of Benetton are manufactured in Tunisia. This mark was made of polemic theses last years by its shocking advertising campaigns. This brand has committed an ethical severity at its advertising campaign by launching a series of ads showing heads of state kissing. The second guide is composed of 7 Tunisian consumers (3 females and 4 males) presents the case of the Nestle mark. The choice of this brand back to the fact that it is rather known everywhere in the world, it is a leader of food of several categories of products. Thus, this brand knew several actions of boycott because of certain made serious acts. This brand has made an economic severity when it has decided to increase the prices of some products by more than $30 \%$. Both marks are presented in the form of articles taken from the press and blogs on the Internet.

The results show that satisfaction, trust and commitment to Benetton will accentuate this form of severity that is qualified as an ethical severity. One interviewee has talked about the ethical perceived severity committed by Benetton:

"I'm going to call in question my relationship with this brand ... Personally my strong relationship with Benetton does not allow me to accept this serious act ...... .My commitment will accentuate the seriousness because it touched my beliefs."

Therefore, consumers do not tolerate the ethical severity committed by Benetton and feel that their strong relationship with the brand will accentuate this form of serious act and thus they may be ready to end the relationship with it. Some interviewees provided some remarks:

"Honestly a brand that does not respect ethical values, does not deserve to be respected ... Personally I am ready to end my 
relationship with this brand (Benetton), although my experience with it is good."

However, we do not find the same observations for the second case of the acts committed by Nestlé. The results point out that the majority of respondents have certainly shown their dissatisfaction with the price increase of their favorite brand, but they say that their strong relationship with this brand may limit such severity that is purely economic. Some respondents say:

"Certainly the Nestlé brand must meet the purchasing power of consumers but I do not think that there is another brand that can satisfy me like it."

Therefore, most respondents assume that they can withstand the increase of prices because their commitment to this brand hinders their looking for another cheaper brand. One interviewee suggested explanations:

"If I'm going to continue my relationship with the brand (Nestlé) it is because I may not find another substitutable product ... and my strong commitment costs more than this high price".

Analyzes have brought a clarification on the concept of the perceived severity of the acts in showing the reaction of consumers engaged with the brand towards various forms of severity. However, the study shows that the decision to participate in the boycott is triggered when it comes to ethical severity where a contrast effect occurs when it is an ethical gravity. Indeed, the confrontation between the relationship with the brand and the advertising campaign danger promoted by the company generates then an aggravation of the offense committed by the brand because touching beliefs and social norms of individuals may call into questioning the judgment of satisfaction, trust, commitment, and all attitudes that the person has developed throughout their consumer experiences. However, the analysis of this study showed that satisfaction, trust and commitment tend to produce effects when assimilation is about a severity of an economic nature (price increase ...), hence such a problem does not affect participation in the boycott. This form of severity joins the type of instrumental boycott that aims to trigger changes influencing business decisions (e.g. changing its pricing policy). As a matter of fact, the more consumers are committed to a brand, the more they tend to minimize the economic severity of acts committed by it, while the more consumers are engaged with a brand, the more they tend to emphasize the ethical severity of acts committed by it.

In synthesis, the results of the qualitative study are in coherence with the literature which suggests that the commitment and the quality of the relation with the mark have no direct influence on the decision of the participation in the boycott. This decision is mediated by perceived severity which is in its turn a factor that limits or accentuates this boycott decision depending on its intensity and type.

We rely on the literature review and the results of the qualitative study to formulate our hypotheses.

\section{Hypothesis Development}

\section{Satisfaction / Commitment}

Satisfaction is regarded as the cumulative result of previous direct experience, i.e. the experience is a key factor in the study of satisfaction because without experience, commitment cannot be established. Similarly, Ben Khelil and Bahri-Ammari, (2013); Garbarino and Johnson (1999) show that if customers are engaged, they must necessarily be satisfied by the brand. The works of Thomson et al. (2005) and Smaoui (2008) show that satisfaction is the basis of commitment.

$\begin{array}{llr}\begin{array}{l}\text { Hypothesis } \\ \text { positively }\end{array} & \begin{array}{r}\text { Customer } \\ \text { influences }\end{array} & \begin{array}{r}\text { satisfaction } \\ \text { customer }\end{array}\end{array}$
commitment.

\section{Trust / Commitment}

The variables of trust and commitment are the result of the relationship between the consumer and the company (Garbarino and Johnson, 1999; Morgan and Hunt, 1994). Thus, the long-term commitment is arbitrary to the notion of trust (Ganesan, 1994). This relationship presupposes that 
commitment is a direct consequence of trust (Gurviez, 2002) and that the higher confidence is, the more important the intensity of the commitment to the brand is.

Hypothesis 2: Customer trust positively influences customer commitment.

\section{Attachment / Commitment}

The tendency to resist a change highlights the link between attachment and commitment (Amin, 1994; Beatty and al. 1988). Attachment is considered as a barrier to the rebranding and justifies the true customer loyalty (Terrace, 2003). Attachment is therefore an emotional commitment factor with the brand (Lacoeuilhe, 2000 and al). Chaudhuri and Holbrook (2002) and Lacoeuille (2000) confirmed the existence of a positive relationship between attachment and commitment.

$\begin{aligned} & \text { Hypothesis 3: } \begin{array}{l}\text { Customer } \\ \text { positively } \\ \text { influences }\end{array} \\ & \text { commitment. }\end{aligned}$

Relational Quality with the brand (satisfaction, trust and commitment) / Perceived Severity

In their empirical research, Zeithaml et al. (1996) show that there is a negative and significant relationship between satisfaction and perceived severity because consumers who are satisfied by their brand must resist the persuasion against competitors and boycott organizers by minimizing the seriousness of the acts committed by the mark. Thus, Rempel et al. (1985) reported a negative relationship between trust and perceived severity. Similarly, Garbarino and Johnson (1999) argue that there is a negative and significant relationship between commitment and perceived seriousness and that commitment to the relationship should indirectly limit participation in the boycott and lead the consumer to reduce the severity of the acts committed by the brand. Indeed, the results of the qualitative study showed that the development of satisfaction, trust and commitment to a brand limit the economic severity of the act of the brand in the instrumental boycott and they accentuate the ethical severity in the expressive boycott.

Hypothesis 4: The customer satisfaction minimizes the economic severity of the act of the brand in the instrumental boycott.

Hypothesis 4a: The customer trust minimizes the economic severity of the act of the brand in the instrumental boycott.

Hypothesis 4b: The customer attachment minimizes the economic severity of the act of the brand in the instrumental boycott.

Hypothesis 5: The customer satisfaction maximizes the ethical severity of the act of the brand in the expressive boycott.

Hypothesis 5a: The customer trust maximizes the ethical severity of the act of the brand in the expressive boycott.

Hypothesis 5b: The customer attachment maximizes the ethical severity of the act of the brand in the expressive boycott.

\section{Perceived Severity / Boycott}

In their empirical work, Klein et al. (2003) stated that there is a positive relationship between perceived severity and the decision to boycott and that the perceived severity of the acts of the brand has a direct influence on the participation in the boycott. Indeed, the results of the qualitative study showed that the different forms of the perceived severity can explain the decision to participate or not in the boycott. When severity is of an economic nature (related to instrumental boycott), consumers continue their relationship with the brand, while when severity is ethical (related to expressive boycott), consumers make an anti-consumption actions and participate in the boycott.

Hypothesis 6: The perceived ethical severity of the act of the brand in the expressive boycott positively influences the decision of participation in the boycott.

Hypothesis 7: The perceived economic severity of the act of the brand in the instrumental boycott positively influences the intention to continue the relation. 


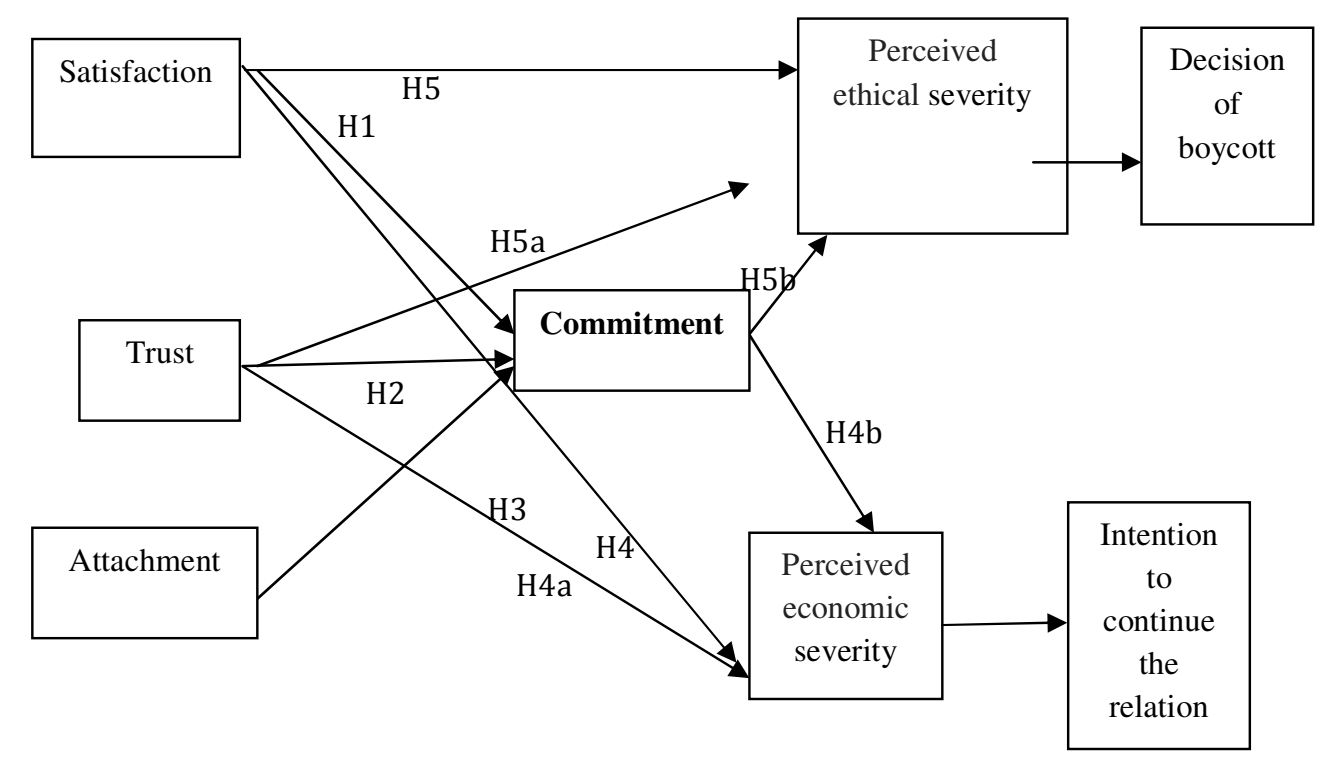

Figure 1: Conceptual Model

\section{Method: Measures}

In order to operationalize the variables, we have developed two scales measuring the perceived severity by incorporating a twodimensional approach to the perceived severity namely: the economic perceived severity and the ethics perceived severity. The items that we selected are from Klein, and John Smith scale, (2003) and verbatim of an exploratory qualitative study that was conducted earlier. We used the paradigm of Churchill (1979) for the construction of measurement scales. The choice to create measurement scales for perceived severity is justified by the theoretical failure on the operationalization of this construct about which the literature offers only one level namely that of Klein and John Smith (2003). This scale has only two items reversed i.e. "What did my brand $\mathrm{X}$ is not so dramatic" and "I think what we blame the brand $\mathrm{X}$ for, is not so bad." This weakened the scale in terms of items from which the items do not respond well to our problem and our research. In addition, this scale studied the concept of perceived severity of the acts committed by the brand as one dimension and as a general concept without distinguishing between the different types and shapes of severity and without considering the consumer's reaction to each form. The first data collection is conducted on a sample of 100 individuals aged between 25 and 45 years, with a proportion of $47.5 \%$ males and $52.5 \%$ females from different socioprofessional categories. The exploratory factor analysis following the first led us to not remove any items because of the good communality (all items include communality> 0.5). We note that the factor structure of the scale of measurement is stable. We conduct a second analysis on the basis of the second collection in order to check and confirm the stability of the measuring instrument. The principal component analysis of the second collection is performed on a sample of 350 individuals. The results of the realized exploratory factorial and confirmatory analysis have shown that the set of indicators is satisfactory which allows ensuring a convergent and discriminant validity of the perceived ethical severity scale and the perceived economic gravity. Each scale contains 7 items. 
Table 1: Indices of Adjustments of the Measurement Model

\begin{tabular}{|c|c|c|c|c|c|c|c|c|c|}
\hline \multicolumn{7}{|c|}{ Indices of adjustments of the measurement model of ethical perceived severity } \\
\hline $\mathrm{X}^{2}$ & $\mathrm{ddl}$ & $\chi^{2} / \mathrm{ddl}$ & $\mathrm{RMR}$ & $\begin{array}{c}\text { RMSE } \\
\text { A }\end{array}$ & GFI & AGFI & TLI & CFI & $\begin{array}{c}\text { BIC/BIC } \\
\text { SATURE }\end{array}$ \\
\hline $\begin{array}{c}18,85 \\
9\end{array}$ & 12 & 1,572 & 0,022 & 0,040 & 0,985 & 0,965 & 0,993 & 0,996 & $\begin{array}{c}90,258 / \\
84,184\end{array}$ \\
\hline \multicolumn{2}{|c|}{ Indices of adjustments of the measurement model of economic perceived severity } \\
\hline$X^{2}$ & ddl & $\chi^{2} / \mathrm{ddl}$ & RMR & $\begin{array}{c}\text { RMSE } \\
\text { A }\end{array}$ & GFI & AGFI & TLI & CFI & $\begin{array}{c}\text { BIC/BIC } \\
\text { SATURE }\end{array}$ \\
\hline 8,689 & 7 & 1,241 & 0,024 & 0,026 & 0,992 & 0,975 & 0,996 & 0,998 & $90,149 / 93,154$ \\
\hline
\end{tabular}

Satisfaction was measured by the scale developed by Sen, Gürhan-Canli and Morwitz (2001) and using 5 items. Trust (scale with 6 items) was taken from Hess (1995). Brand attachment was measured by the scale developed by Lacoeuille, (2000), and using 5 items. Commitment

\section{Sample and data collection}

In order to better carry out this study, we first established a pre-test to 50 individuals in order to choose the product category and brand. We proposed a list that contains three brands belonging to three categories. The three brands are: President, Samsung, and Celio. In fact, we increased the choice of three different product categories: Cheese, Mobile phone, Clothing. We have asked respondents to rate their level of involvement with the product category and the degree of commitment to the brands. The evaluation was made on a scale of five positions. The results have led us to choose the brand that has both a strong commitment and a strong involvement of the product category namely: Celio brand. We used non probabilistic and convenience sampling. This method is made up of selected elements because they are (scale with 3 items) was taken from John and Klein (2003). Items for the intention to continue the relation ( 3 items) was taken from Tax (1997) scales of behavioral intentions. Boycott, was measured by scale using 6 items and developed by N'Goala (2009).

available, easy to join and convince to take part in our research. The sample was made up of 350 respondents who were directly interviewed in Celio stores. The interviews lasted about 20 minutes in order to prevent boredom. To ensure the good comprehension of the questions by the respondents, a pre-test was made near 35 customers ( $10 \%$ of the sample).

\section{Results}

\section{Measure purification and reliability}

Scales were assessed using reliability analysis. Most reliability ranged from 0,702 to 0,926 , which allows us to accept these indicators. Test results revealed that all variables are unidimentional and explain more than $45 \%$ of the variance extracted. All the values of KMO are higher than 0,6. Items and factors are presented in Table 2. 
Table 2: Purified Measurement Items of Selected Variables

\begin{tabular}{|c|c|c|c|c|}
\hline $\begin{array}{c}\text { Measurement } \\
\text { scales }\end{array}$ & Structure & $\begin{array}{c}\text { Cumulative } \\
\text { variance } \\
\text { explained }\end{array}$ & Reliability & KMO test \\
\hline Satisfaction & Unidimentional & $44,948 \%$ & 0,797 & 0,773 \\
\hline Trust & Unidimentional & $47,765 \%$ & 0,744 & 0,801 \\
\hline Attachment & Unidimentional & $52,951 \%$ & 0,710 & 0,710 \\
\hline Commitment & Unidimentional & $62,720 \%$ & 0,702 & 0,613 \\
\hline $\begin{array}{c}\text { Perceived } \\
\text { ethical severity }\end{array}$ & Unidimentional & $69,647 \%$ & 0,924 & 0,911 \\
\hline $\begin{array}{c}\text { Perceived } \\
\text { economic } \\
\text { severity }\end{array}$ & Unidimentional & $58,205 \%$ & 0,853 & 0,856 \\
\hline $\begin{array}{l}\text { Intention to } \\
\text { continue the } \\
\text { relation }\end{array}$ & Unidimentional & $84,043 \%$ & 0,902 & 0,756 \\
\hline Boycott & Unidimentional & $73,492 \%$ & 0,926 & 0,922 \\
\hline
\end{tabular}

\section{Measurement model fit}

The results of confirmatory factor analysis are all acceptable. The loadings are all significant and Squared Multiple Correlation (SMC) values are higher than 0.5. This analysis was developed on the different measures to examine the reliability and validity. The fit indices are good and the values of $\chi 2$ are acceptable (lower than 3) (Table 3). All factors have a
Rho Jöreskog higher than 0.7 which verifies the reliability of measurement scales. The scales reliability and convergent validity are also tested. Also, the discriminant validity results (Table 4 and 5) of the different constructs are ensured because the rho convergent validity is significantly higher than the squared correlations with other variables (Fornell and Larcker, 1981).

Table 3: The Results of Confirmatory Factor Analysis

\begin{tabular}{|l|l|l|l|l|l|l|l|}
\hline Factors & $\begin{array}{l}\text { Chi-deux } \\
\text { normé }\end{array}$ & GFI & AGFI & RMR & RMSEA & TLI & CFI \\
\hline Satisfaction & 1,323 & 0,992 & 0,977 & 0,041 & 0,030 & 0,986 & 0,977 \\
\hline Trust & 0,316 & 0,998 & 0,995 & 0,020 & 0,040 & 0,954 & 0,909 \\
\hline Attachment & 0,284 & 0,999 & 0,996 & 0,014 & 0,031 & 0,941 & 0,910 \\
\hline Commitment & 1,571 & 0,900 & 0,909 & 0,028 & 0,020 & 0,927 & 0,912 \\
\hline $\begin{array}{l}\text { Perceived } \\
\text { ethical } \\
\text { severity }\end{array}$ & 1,572 & 0,985 & 0,965 & 0,022 & 0,040 & 0,993 & 0,996 \\
\hline $\begin{array}{l}\text { Perceived } \\
\text { economic } \\
\text { severity }\end{array}$ & 1,241 & 0,992 & 0,975 & 0,024 & 0,026 & 0,996 & 0,998 \\
\hline $\begin{array}{l}\text { Intention to } \\
\text { continue the } \\
\text { relation }\end{array}$ & 2,357 & 0,905 & 0,914 & 0,020 & 0,022 & 0,951 & 0,991 \\
\hline & 1,966 & 0,984 & 0,963 & 0,024 & 0,040 & 0,990 & 0,994 \\
\hline
\end{tabular}




\section{Structural model}

The results of confirmatory factor analysis indicate that the model fit to the data is acceptable $\left(\mathrm{X}^{2} / \mathrm{df}=1380,450 / 678=2,036\right.$; GFI $=0,820 ; \quad \mathrm{AGFI}=0,793 ; \quad \mathrm{RMR}=0,067$; RMSEA=0,054; TLI=0,919; CFI=0,926). In this research, the model fit is accepted and confirms the conceptual model proposed. The Results of structural model revealed respectively that the satisfaction, trust and attachment influence positively customer commitment $(\mathrm{t}=2,751, \mathrm{p}=0,000 ; \mathrm{t}=2,298$; $p=0,006 ; t=2,404, p=0,000)$. Supporting $\mathrm{H} 1, \mathrm{H} 2$ and $\mathrm{H} 3$. The relationship between satisfaction and perceived economic severity is not significant $(t=1,170$; $\mathrm{p}=0,242$ ). Then, we rejected H4. Whereas, the hypothesis that stipulates that customer trust (H4a) and commitment
(H4b) minimize the economic severity of the act of the brand in the instrumental boycott were confirmed with high contributions. The hypotheses that stipulate that customer satisfaction (H5), trust (H5a) and commitment (H5b) maximize the ethical severity of the act of the brand in the expressive boycott were also supported. In fact, the results revealed that the perceived ethical severity of the act of the brand in the expressive boycott has a positive and significant effect on the decision of boycott $(t=17,805 ; \mathrm{p}=0,000)$, supporting H6. However, when the perceived severity of the brand is economic, the costumer will have the intention to continue the relation with the brand ( $\mathrm{t}=12,264 ; \mathrm{p}=0,000), \mathrm{H} 7$ was confirmed.

Table 4: Results of Reliability and Convergent Validity

\begin{tabular}{|l|l|l|}
\hline Factors & $\boldsymbol{A V E}$ & $\begin{array}{l}\text { Convergent Validity } \\
\text { (Rhô de Joreskog) }\end{array}$ \\
\hline Satisfaction & 0,739 & 0,741 \\
\hline Trust & 0,845 & 0,801 \\
\hline Attachment & 0,791 & 0,874 \\
\hline Commitment & 0,884 & 0,612 \\
\hline Perceived ethical gravity & 0,901 & 0,705 \\
\hline Perceived economic gravity & 0,875 & 0,835 \\
\hline Boycott to continue the & 0,914 & 0,693 \\
\hline $\begin{array}{l}\text { Intention } \\
\text { relation }\end{array}$ & 0,788 & 0,598 \\
\hline
\end{tabular}


Table 5: Discriminant Validity

\begin{tabular}{|c|c|c|c|c|c|c|c|c|}
\hline & Satisfaction & Trust & Attachment & Commitment & $\begin{array}{l}\text { Ethical } \\
\text { severity }\end{array}$ & $\begin{array}{l}\text { Economic } \\
\text { severity }\end{array}$ & Boycott & $\begin{array}{l}\text { Intention } \\
\text { to } \\
\text { continue } \\
\text { the } \\
\text { relation }\end{array}$ \\
\hline Satisfaction & 0,741 & & & & & & & \\
\hline Trust & 0,024 & 0,801 & & & & & & \\
\hline Attachment & 0,018 & 0,010 & 0,874 & & & & & \\
\hline Commitment & 0,015 & 0,002 & 0,051 & 0,612 & & & & \\
\hline $\begin{array}{l}\text { Perceived } \\
\text { ethical } \\
\text { severity }\end{array}$ & 0,053 & 0,005 & 0,036 & 0,026 & 0,705 & & & \\
\hline $\begin{array}{l}\text { Perceived } \\
\text { economic } \\
\text { severity }\end{array}$ & 0,040 & 0,003 & 0,583 & 0,573 & 0,012 & 0,835 & & \\
\hline Boycott & 0,350 & 0,339 & 0,030 & 0,032 & 0,005 & 0,015 & 0,598 & \\
\hline $\begin{array}{l}\text { Intention to } \\
\text { continue the } \\
\text { relation }\end{array}$ & 0,119 & 0,303 & 0,026 & 0,001 & 0,009 & 0,438 & 0,084 & 0,693 \\
\hline
\end{tabular}

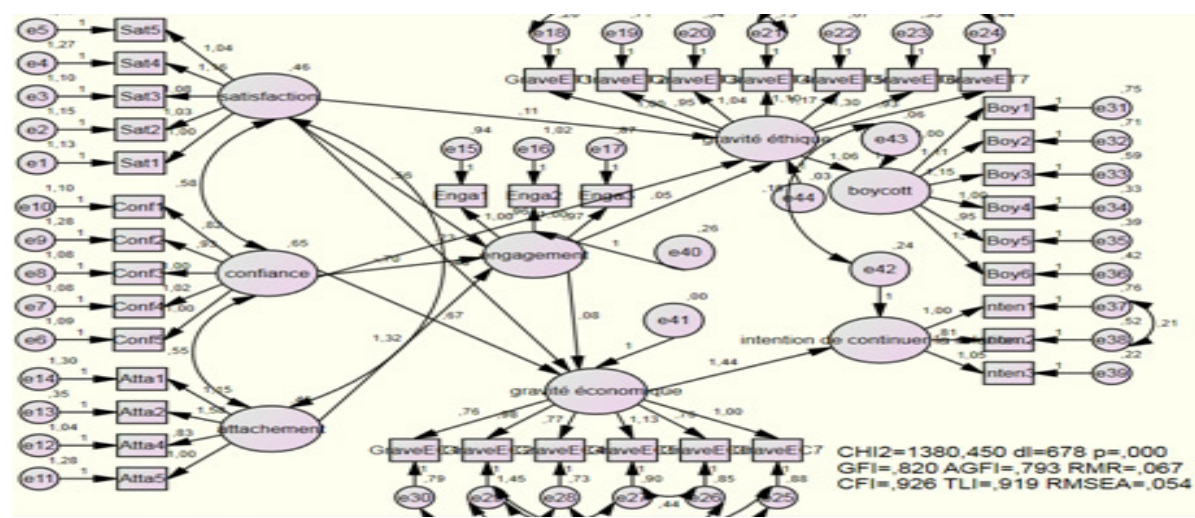

Figure 2: Model test results

\section{Discussion and conclusion}

This research has attempted to test a theoretical model that implements the impact of the commitment and the quality of relationships with the brand on consumer participation in a boycott. From the literature review and the exploratory research, we found that the perceived severity plays a key role in the continuity or rupture of the consumer relationship with the brand. The results show that satisfaction, trust and commitment are the main antecedents of commitment. These results were expected because many researchers checked the links and considered that these three relational variables are the main determinants of commitment and are the dimensions of a relational quality brand (Terrace, 2006). Referring to the literature on relational marketing, researchers then become interested in the concept of consumerbrand relationship (Albert and Florence Valletta, 2008b). This relationship is "not a mere abstraction, it is a person who has his own features, who attracts, seduces, that lead to dream that one can even cherish, love and why not engage for life. "(Bayarassou et al., 2010, p.1).

For the assimilation effects of the quality of the relationship with the brand, they have appeared when we issued the set of 
assumptions showing that the variables of relationship quality (satisfaction, trust and commitment) minimize the economic severity of the act of the brand in the instrumental boycott. The results show that the quality of the relationship with the brand tends to minimize the perceived severity of the acts of an economic nature except satisfaction. These results go in the same path with the results of the exploratory study that showed that trust and commitment in the relationship limit the boycott decision-making when they come to the severity committed by the mark and are of an economic nature (usually abusive price increases). Therefore, we conclude that although consumers are confident and committed to the brand, they tend to minimize the severity of the economic actions that are derived during a call to an instrumental boycott (abusive price increases, noncompliance with the power of consumer purchasing, ..), in order to maintain their cognitive, conative and emotional balance and preserve their system of attitudes and beliefs. In the end, the commitment and the quality of the relationship with the brand tend to generate the assimilation effects when a negative process of information about the brand is observed (Ahluwalia, Burnkrant and Unnava, 2000 and 2001). It, then, pushes the consumer to change the way by which they determine the perception of economic perception of the act committed by the brand in the case of an instrumental boycott. Reminding that this type of boycott, as we have presented it in the literature review, is a reaction to a serious act committed by the company, this act is generally qualified to be of an economic nature, aiming at creating a change, putting a pressure on the company to change its policy and bringing down the price of a particular product.

However, the contrasting effects of the quality of the relationship with the brand are triggered when we issued the set of hypotheses stating that satisfaction, trust and commitment maximize the ethical severity of the act of the brand in the expressive boycott. The results showed that these variables, which form the quality of the relationship, tend to maximize the severity of the act of an ethical nature. We note that these results converge with the results of the exploratory research which suggested that commitment and quality of the relationship with the brand accentuate the consumer's participation in the boycott when it is a serious act of an ethical nature committed by the brand. In contrast to the effect of assimilation of the quality of the relationship, the contrast effect is related to the existence of a stimulus in the rejection margin. The consumer should then maximize the difference between the stimulus (call to boycott) and the anchoring point (attitudes and beliefs about the brand). The gap, then, seems so huge between the expected behavior of the mark (perceived values and benefits, favorable experiences of past consumption...) and their actual behavior. This confirms the findings of Klein, and John Smith (2003) also brought in the case of social boycott (exploitation of child labor in the Third World, massive layoffs of workers...). So, when the cause is moral, the temptation for individuals is lower to resume their freedom when they will be more likely to cooperate with the boycotters (Sen Gürhan-Canli and Morwitz, 2001; John and Klein, 2003). However, when it comes to the personal impact on the consumer's purchasing power such as pressuring to reduce prices of the brand, this is not necessarily considered a sacrifice to make. Indeed, the confrontation between the main beliefs and attitudes of the individual in relation to the performance of the mark (anchoring point) and gross negligence (stimulus) contributes in worsening more the fault committed by the brand. Satisfaction, trust and brand's commitment therefore have a strong effect in participation in the boycott, which is not surprising when it is severity that touches religion so the consumer's religious belongings reflect their behaviors, perceptions and especially their consumption and purchasing habits (Grégoire and Fisher, 2006).

However, when the severity of the act is of an economic nature, (instrumental boycott) consumers will intend to continue their relationship with the brand. These results converge to the results of the previous research and the exploratory study. Indeed, in the case of an expressive boycott (religion, taboo...), consumers are likely to join the boycott action. According to the literature review, when the mark is in conflict with the beliefs and values of the 
consumer, this is a major factor in triggering the boycott. Moreover, when it comes to traditional moral and societal benchmarks or even the transgression of certain ethical principles (Grégoire, Laufer and Tripp, 2010), individuals become aware of the potential impact on society and do not perceive that the nonconsumption as a sacrifice. The perceived seriousness of ethical corporate acts was considered the key variable to participate in the boycott. However, in the case of the economic severity committed by the brand in the instrumental boycott, the results show that although consumers consider that prices are abusive, exorbitant and unfair, they will have the same tendency to produce an assimilation effect and generate a plan to continue to buy the brand and continue the relationship with it. In this regard, individuals engaged with the brand should mitigate the perceived economic gravity. These results go in the same direction of Webster research, (1992). Thus, we can confront and confirm the results obtained with the literature review.

\section{Managerial implications}

This research brings contributions to the managerial level in the sense that it is considered to be one of the first studies to compare different types of the perceived severity of the acts committed by the brand and show their mediating role between the relational quality and the boycott. Managers should benefit from the good quality of the relationship of consumers to the brand (Dawar and Pillutla, 2000) so they must seize this opportunity and try to convince consumers by the actions of the brand using direct marketing tools to target communities brands to change their perception towards serious acts (Muniz and O'Guinn, 2001). A marketing campaign might then try to appease the guilt of the company (Dolnicar and Jordaan, 2007). Indeed, the good qualities of relationships and commitment to the brand can be considered as a "form of insurance" to counter all the information about the blatant conduct of the brand. Since the boycott action may have serious consequences on companies, beyond any direct loss of revenue, there are also longterm impacts that affect the company reputation and the brand image. The role of managers seems important in this case; they have an interest in conducting social audits and implement the principles of corporate social responsibility (CSR) in order to remedy the engendered problem and further embellish the company's brand image (Smith, 2005).

In the end, managers should not suppose that "non-boycotters" are not affected by the boycott. An important lesson they must recognize is that "non-boycotters' can strongly disapprove with the company's practices and become potential boycotters in the future.

\section{Limitations and future research}

This research paves the way to better understand the relational quality brand's effect on the participation in the boycott. The fact has some limitations: The methodology (the use of a questionnaire survey) leads to relying on fictitious behaviors. However, the use of experimentation could have allowed to study the real behavior and to compare the effect of relational quality on the boycott on homogeneous samples such as lifestyle, age, gender, ... This research has demonstrated the intention to boycott, that is to say the decision to end the relationship with the company in response to the serious behavior of the brand, but the limit of this research is that it does not consider the real and effective behavior of the boycott. Indeed, there may be a gap between what is said and what consumers actually do when they perceive such severity act. We suggest the need to use new longitudinal approaches in order to follow, in time, the consumer's behavior and its response to each type of boycott call.

This research presents a phase in a mediating role of explanation process between perceived severity, relational quality and the boycott. Indeed, in order to overcome the limitations discussed below, we will suggest a number of reflections and investigations of possible fields. This study was limited to examine the role of the severity of the acts of the brand in the consumer's participation in a boycott, but there are other additional factors that may be considered such as credibility of the message, probability of success, switching costs of the usual brand, etc. Indeed, in 
order to better understand the consumer's motivations in participating in a boycott, future research work should examine the role of individual differences in the boycott decision e.g. gender, age, culture, personality, lifestyle, ... In addition, we considered two types of severity: ethical severity and economic severity. But, future research may examine other types of severity such as safety severity and social severity. Finally, future studies should investigate the role of the Internet in the call for boycotts especially today with the development of Facebook and social networks; consumer groups can initiate calls to boycott through these networks, buzz marketing and participatory Web (Web 2.0). In this context, we can cite the example of the social network "Hatebook" which is inspired from "Facebook": an antisocial way contributing to know the attitudes towards brands and all what Internet users hate (Romani, and Sadeh Dalli, 2009). There are indeed many "hate groups" on Hatebook and who invite the group members to share their discontent and anger toward a brand or an object...

\section{Appendix1: Measurement Items are Shown Below}

\begin{tabular}{|c|c|}
\hline Constructs & Items \\
\hline Satisfaction & $\begin{array}{l}\text {-I'm happy of the relationship I have established with this } \\
\text { brand. } \\
\text { - I love this } \\
\text {-I Am delighted of the habits with this brand. } \\
\text {-I Am satisfied by of this brand } \\
\text {-I Have done well to choose this brand. }\end{array}$ \\
\hline Trust & $\begin{array}{l}\text {-Brand A would do absolutely all that is in its power to help } \\
\text { its customers to solve the problems to which they will be } \\
\text { able to cope. } \\
\text {-Brand A is entirely committed to satisfy its customer. } \\
\text {-Brand A would do anything to satisfy its customers. } \\
\text {-When I see a publicity of brand A, I trust him. } \\
\text {-I am committed to continue my business relationship with } \\
\text { this brand. } \\
\text {-If brand A affirms or promises something in } \\
\text { with one of its products it is probably true. }\end{array}$ \\
\hline Attachment & $\begin{array}{l}\text {-I have great affection for this brand. } \\
\text { - I am somehow related to this brand. } \\
\text { - This brand gives me pleasure. } \\
\text { - I finf a confort to use the products or services of this } \\
\text { brand. } \\
\text { - I am very attracted by this brand. }\end{array}$ \\
\hline Commitment & $\begin{array}{l}\text {-I'd be happy to remain client of this } \begin{array}{l}\text { brand. } \\
\text {-I Am this }\end{array} \text { brand. } \\
\text {-I Find it difficult to change the brand. }\end{array}$ \\
\hline Ethical severity & $\begin{array}{l}\text {-I Am ready to change this brand if it touchs my attitudes. } \\
\text {-My Strong relationship with the brand does not allow me } \\
\text { to forgive it makes a moral gravity. } \\
\text {-It Is very serious when a brand touches on ethics or } \\
\text { religion. } \\
\text {-My Strong commitment to the brand pushes me to tolerate } \\
\text { certain acts considered to be serious. } \\
\text {-I Am shocked by the behavior of this brand, I find it } \\
\text { dangerous. } \\
\text {-I'm Surprised by the serious act of the brand, it deserves to } \\
\text { be }\end{array}$ \\
\hline
\end{tabular}


- Which that the made gravity, I will not change this brand.

\section{Appendix1: Measurement Items are Shown Below}

\begin{tabular}{|c|c|}
\hline Economic severity & $\begin{array}{l}\text {-This act of the brand is as dramatic, I find an interest to } \\
\text { break my relationship ith } \\
\text { - It will be very difficult for me to change the brand, I still } \\
\text { continue to enjoy it. } \\
\text {-I Tend to defend the brand, even if it increases its prices. } \\
\text {-I will buy this brand; even its prices become higher than } \\
\text { those of the competitors. } \\
\text {-I Am not ready to pay a little more for this brand. } \\
\text {-If This brand decides to strongly increase its prices that } \\
\text { would change my habits of spending. } \\
\text {-The Quality of my relationship with the brand limits the } \\
\text { perception of the seriousness that it has committed. }\end{array}$ \\
\hline $\begin{array}{l}\text { Intention to continue the } \\
\text { relation }\end{array}$ & $\begin{array}{l}\text {-In The future, I want to continue to buy this brand. } \\
\text {-It Is likely that I will continue to buy this brand the next } \\
\text { time. } \\
\text {-It's a pleasure to buy this brand the next time. }\end{array}$ \\
\hline Boycott & 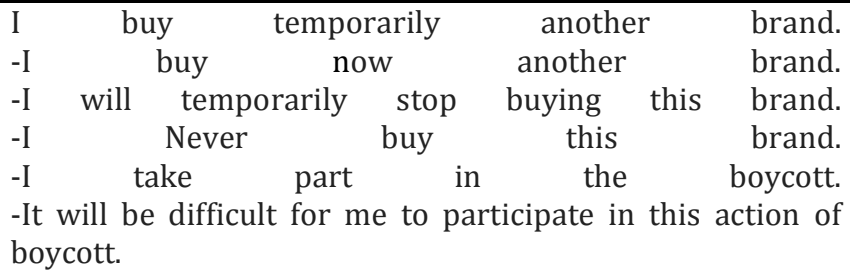 \\
\hline
\end{tabular}

\section{References}

1. Abeele et Gendolla, (1999), "Satisfaction judgments in positives and negatives moods: Effects of concurent assimilation and contrast producing processes, personality and social psychology", bulletin 25, 7, June 883-895.

2. Ahluwalia R., Burnkrant R.E. et Unnava H.R. (2000), "Consumer response to negative publicity: the moderating role of commitment", Journal of Marketing Research, 37, 2, 203-214.

3. Ahluwalia R. Unnava H., Burnkrant R. (2001), "The moderating role of commitment on the spillover effect of marketing communications". Journal of
Marketing Research, Vol. 38 Issue 4, p. 458470,13p.

4. Albert, N., Merunka, D., ValetteFlorence, P., (2008b), "The love feeling toward a brand: Concept and measurement", Advances in Consumer Research 36, 300-307.

5. Amine A. (1994), " Implication du consommateur et fidélité aux marques », Cahier de recherche 235, DMSP.

6. Aurier P., Benavent C. et N'Goala G. (2001), «Validité discriminante et prédictive des composantes de la relation a la marque », 17ème Congrès International de l'Association Française de Marketing, mai 2001. 
7. Bayarassou O., Ghrib H., Becheur I. et Albert N. (2010), «Amour pour la marque, Personnalité de la marque et engagement affectif : liens et impacts, 9e colloque international de la recherche en marketing ", Association Tunisienne $d u$ Marketing, 8-9 avril, Hammamet.

8. Beatty S., Homer P., Kahle L. (1998), "the involvement-commitment model: theory and implications", Journal of Business Research, 16 (2) 149-167.

9. Belk R.W. (1992), "Attachment to Possessions", in Irwin A. et Setha M.L., Place Attachment and Human Environment, 12, New York, Plenum Press, 37-62.

10. Ben Khelil H. ; Bahri-Ammari N. (2013), «L'attachement à la marque et ses conséquences sur le prosélytisme et la résistance aux changements ", $2^{\text {ème }}$ colloque international de l'Association Maghrébine de Marketing (AMM), Hammamet, Tunisie.

11. Ben Khelil H; Bouslama N. (2014), «L'impact de la qualité de la relation à la marque sur le comportement de fidélité du consommateur: Application sur le secteur de télécommunication en Tunisie», $5^{\text {ème }}$ journées de l'Unité de Recherche et Applications en Marketing (URAM), Hammamet, Tunisie.

12. Berry, L.L. (1995), "Relationship marketing of services - growing interest, emerging perspectives", Journal of the Academy of Marketing Science, Vol. 23 No. 4, pp. 236-45.

13. Chaudhuri A. et Holbrook M.B. (2002), "Product-class Effects on Brand Commitment and BrandOutcomes: The Role of Brand Trust and Brand Affect", Brand Management, 10, 1, September, 33-58.

14. Chen J, Wan Y, Sun Y and Tao F. (2014), «Relations between problems on sleeping and suicidal behaviors in middle school students ». Zhonghua Liu Xing Bing Xue Za Zhi 35 (2) 129 - 33.

15. Chen T-Y., Hung K-P., Tseng C-M., (2010), "The effects of learning capacity, transparency and relationship quality on inter-organizational learning",
International Journal of Management, 27, 3, $405-420$.

16. Choo H.J., Jung J-W., Chung I.H., (2009), Buyer-supplier relationships in Dongdaemun fashion market: relationship quality model, Journal of Fashion Marketing and Management, 13, 4, 481 - 500

17. Chung K-H., Shin J-I., (2010), "The antecedents and consequents of relationship quality in internet shopping", Asia Pacific Journal of Marketing and Logistics, 22, 4, 473 - 491.

18. Churchill G A. (1979), "A paradigm for developing better measures of marketing constructs", Journal of Marketing Research, 16 February, 64-73.

19. Dawar Niraj, Pillutla Madan M. (2000), "Impact of product-harm crises on brand equity: the moderating role of consumer expectations", Journal of Marketing Research, 2000;37(2):215-26.

20. DeWulf K., Odekerken-Schroder G. et Iacobucci D. (2001), "Investments in consumer relationships: a cross-country and cross-industry exploration", Journal of Marketing, 65, 4, 33-50.

21. Dolnicar S. et Jordaan Y. (2007), “A market-oriented approach to responsibly managing information privacy concerns in direct marketing", Journal of Advertising, $36,2,123-149$.

22. Festinger L. (1957), "A theory of cognitive dissonance", Evanston, Row, Peterson and Compagny.

23. Filser M. (1994), « Le comportement $d u$ consommateur », Paris, Éditions Dalloz.

24. Fishbein, M., \& Ajzen, I. (1981), "Attitudes and voting behavior: An application of the theory of reasoned action. In G. M. Stephenson \& J. M. Davis (Eds.)", Progress in Applied Social Psychology (Vol. 1, pp. 253-313). London: Wiley.

25. Friedman M. (1985), "Consumer boycotts in the United States, 1970-1980: contemporary events in historical perspective", Journal of Consumer Affairs, $19,1,96-117$ 
26. Friedman M. (1999), "Consumer boycotts: effecting change through the marketplace and the media", New York, Routledge.

27. Frisou J. (2008), «Les bons points font ils les bons clients? Dynamique de l'accumulation et dynamique du remboursement», International Congress «Marketing Trends» Venice, 17th-19th January 2008.

28. Gabriel Y. et Lang T. (1995), "The unmanageable consumer: contemporary consumption and its fragmentations", Londres, Sage Publications.

29. Ganesan S; (1994), "Determinants of long term orientation in buyer-seller relationship », Journal of marketing, vol 58, pp1-19.

30. Garbarino E. et Johnson M.S. (1999), "The different roles of satisfaction, trust, and commitment in consumer relationships", Journal of Marketing, 63, 2, 70-87.

31. Garrett D.E. (1986), "Consumer boycotts: are targets always the bad guy"?, Business and Society Review, 58, 2, 17-21.

32. Garrett D.E. (1987), "The effectiveness of marketing policy boycotts: environmental opposition to marketing", Journal of Marketing, 51, 2, 46-57.

33. Ghiglione R et Matalon B. (1978), « Les enquêtes sociologiques », Théories et pratiques Paris : A. Colin.

34. Grégoire, Y., \& Fisher, R. J. (2006). "The effects of relationship quality on customer retaliation", Marketing Letters, 17, 31-46 (January).

35. Grégoire, Y., Laufer, D., \& Tripp, T. M. (2010), «A comprehensive model of customer direct and indirect revenge: Understanding the effects of perceived greed and customer power", Journal of the Academy of Marketing Science, 38(6), 738758. Customer retaliation. Marketing Letters, 17, 31-46.

36. Gurviez P. (1998), «La confiance du consommateur dans la marque, conceptualisation, mesure et management ", 14ème Congrès de l'Association Française du Marketing, p. 7396.

37. Gurviez P. et Korchia M. (2002), "Proposition d'une échelle de mesure multidimensionnelle de la confiance dans la marque », Recherche et Applications en Marketing, 17, 3, 41-62.

38. Heilbrunn B. (1996), "Consumer Values and Brand Attachment", 49ème congrès ESOMAR, Changing Business Dynamic, 122-137.

39. Hennig-Thurau T., Gwinner K.P. et Gremler D.D. (2002), "Understanding relationship marketing outcomes: an integration of relational benefits and relationship quality", Journal of Service Research, 4, 3, 230-247.

40. Huntley, Scott. (2006),"Let the ODS PRINTER Statement Take Your Output into the Twenty-First Century." Proceedings of the SAS User's Group International Conference 2006, Cary, NC: SAS Institute Inc.

41. John A. and Klein J.G. (2003), "The boycott puzzle: consumer motivations for purchase sacrifice", Management Science, 49, 9, 1196-1209.

42. Jolley B., Mizerski R., and Doina 0. (2006), "How Habit and Satisfaction Affects Player Retention for Online Gambling", Journal of Business Research, 59, pp. 770777.

43. Klein J. G., N. C. Smith and A. John (2003), "Why We Boycott: Consumer Motivations for Boycott Participation and Marketers Responses", Centre for Marketing, London Business School, 1-39.

44. Klein J.G., Smith N.C. and John A. (2004), Why we boycott: consumer motivations for boycott participation, Journal of Marketing, 68, 3, 92-109.

45. Kozinets R.V. et Handelman J. (1998), "Ensouling consumption: a netnographic exploration of the meaning of boycotting behavior, in J.W. Alba et J.W. Hutchinson (coord.)", Advances in Consumer Research, 
25, Provo, Utah, Association for Consumer Research, 475-480.

46. Lacoeuilhe J. (2000), «Le concept d'attachement : contribution à l'étude du rôle des facteurs affectifs dans la formation de la fidélité à la marque", Thèse de Doctorat en Sciences de Gestion, Université de Paris 12, Val de Marne.

47. Liuz Z., Zeng F., Su C., (2009), "Does relationship quality matter in consumer ethical decision making? Evidence from China, Journal of Business Ethics, 88, 483 496.

48. MimouniA., Volle P., (2003), «Bénéfices perçus de la fidélisation et qualité relationnelle : une application exploratoire au secteur du transport aérien », Actes du 19ème congrès International de l'AFM, Gammarth-Tunis, 9 et 10 Mai, 1-28.

49. Moliner M.A., (2009), "Loyalty, perceived value and relationship quality in healthcare services", Journal of Service Management, 20, 1, 76 - 97.

50. Moorman C., Zaltman G. et Deshpandé R. (1992), "Relationships between providers and users of market research: the dynamics of trust within and between organizations", Journal of Marketing Research, 29, 3, 314-328.

51. Morgan, Robert M. et Hunt Shelby D. (1994), "The Commitment-Trust Theory of Relationship Marketing:' Journal of Marketing, 58 (Juillet), 20-38.

52. Muniz, Albert M. Jr. and Thomas $C$ O'Guinn (2001), "Brand community," Journal of Consumer Research, 27 (4).

53. N'Goala G. (2003), « Proposition d'une conceptualisation et d'une mesure relationnelle de la fidélité », 19ème Congrès de l'Association Française du Marketing, Tunis.

54. N'Goala G. Karine Cissé-D. (2009) : "Les effets de la satisfaction, de la confiance et de l'engagement vis-à-vis d'une marque sur la participation des consommateurs à un boycott», Recherche et Applications en Marketing, vol. 24, $\mathrm{n}^{\circ}$ $1 / 2009$.
55. Oliver R.L. (1997), "Satisfaction: a behavioral perspective on the consumer", Mc Graw-Hill International Editions.

56. Onkvisit S., and Shaw J. (1987), "Self Concept and Image, Congruence: Some Research and Managerial Implication", Journal of Consumer Marketing, 4, 1, pp. 1323.

57. Penaloza L. et Price L.L. (1993), "Consumer resistance: a conceptual overview, in L. McAlister et M. Rothschild (coord.)", Advances in Consumer Research, 20, Provo, Utah, Association for Consumer Research, 123-128.

58. Poncin I. et Pieters R. (2002), «Effets d'assimilation et de contraste dans les réactions affectives induites par les annonces télévisées : l'impact de la similarité thématique et $\mathrm{du}$ mode de traitement», Actes du 18e Congrès international de l'Association Française de Marketing, Lille, 331-350.

59. Qin S., Zhao L., Yi X., (2009), "Impacts of customer service on relationship quality: an empirical study in China", Managing Service Quality, 19, 4, 391 - 409.

60. Rempel J.K., Holmes J.G. et Zanna M.P. (1985), "Trust in close relationships", Journal of Personality and Social Psychology, $49,1,95-112$.

61. Roux D. (2014), "Macromarketing Issues on the Sidewalk : How "Gleaners" and "Disposers" (Re)Create a Sustainable Economy», Journal of Macromarketing, forthcoming.

62. Schouten J.W.; Mc Alexander J.H (1985), "subcultures of consumption: an ethnography of new bikers", Journal of Consummer Research.

63. Sen S., Gürhan-Canli Z. et Morwitz V. (2001),“Withholding consumption: a social dilemma perspective on consumer boycotts", Journal of Consumer Research, $28,3,399-417$.

64. Sherif C.W. (1963), "Social categorization as a function of latitude of acceptance and series range", Journal of 
Abnormal and Social Psychology, 67, 2, 148156.

65. Sheth, J. N. and Parvatiyar, A (Eds) (2000): "Handbook of relationship Marketing, Sage Publications, Thousand, Oak, CA".

66. Sirieix L. et Dubois P.-L. (1999), «Vers un modèle qualité satisfaction intégrant la confiance »?, Recherche et Applications en Marketing, 14, 3, 1-22.

67. Smaoui F. (2008), «Les déterminants de l'attachement émotionnel à la marque : Effet des variables relationnelles et des variables relatives au produit», 7ème Congrès des Tendances Marketing Venise 17-19 janvier 2008.

68. Smith N.C. (2005), "Consumer activism: boycotts, brands and marketing communications, in G. Menon et A.R. Rao (coord.)", Advances in Consumer Research, 32, Duluth, MN, Association for Consumer Research, 494-494.

69. Terrasse, C, (2003) : "proposition et validation d'une échelle de l'engagement à la marque" actes de congrès international de l'AFM.

70. Terrasse, C, (2006), "L'engagement envers la marque : proposition d'un modèle théorique et application à la comparaison de la fidélité aux marques nationales et aux marques de distributeurs", Thèse de doctorat en sciences de gestion, Ecole HEC, Jouy en Josas.

71. Thomson M. et McInnis D.J et Park C.W., (2005), "The Thies that Bind: Measuring the Strength of Consumer's Emotional Attachments to Brands", Journal of Consumer Psychology, 15(1), 77-91.

72. Vesel P., Zabkar V., (2010), "Comprehension of relationship quality in retail environment", Managing Service Quality, 20, 3, 213 - 235.

73. Webster F-E; (1992), "The changing role of marketing in corporation", Journal of marketing, vol 56, pp 1-17.

74. Woo K-S., Ennew C.T., (2004), "Business-to-business relationship quality. An IMP interaction-based conceptualization and measurement", European Journal of Marketing, 38, 9/10, $1252-1271$.

75. Zeithaml V.A., Berry L.L. and Parasuraman L.A. (1996), "The behavioral consequences of service quality", Journal of Marketing, 60, 4, 31-46. 